\title{
PERANAN GURU PROFESIONAL DALAM PENINGKATAN PRESTASI SISWA DAN MUTU PENDIDIKAN DI ERA MILENIAL
}

\author{
Nur Illahi \\ Dosen STAI Asy-Syukriyyah Tangerang \\ nur.illahi@asy-syukriyyah.ac.id
}

\begin{abstract}
Abstrak
Guru professional adalah guru yang mampu mendidik anak muridnya menjadi generasi yang mampu bersaing dan memiliki moral yang baik.Untuk mencapai pendidik yang baik maka para pendidik hendaknya mampu memiliki karakter yang baik pula.Profesionalitas guru sangat penting bagi peserta didik karena guru mempunyai tugas yang sangat berat dalam mendidik mengarahkan dan memotivasi peserta didik untuk menjadi siswa yang pandai dan bermoral.Karakteristik adalah suatu sifat yang baik yang harus dimiliki atau di kuasai oleh seorang pendidik untuk menghasilkan suatu generasi yang bermartabat dan berakhlak.Metode pengajaran profesional adalah cara pendidik dalam menyampaikan atau mengajar peserta didik dimana metode pengajaran yang tepat dapat mendorong semangat peserta didik untuk menjadi lebih giat dalam belajar dan juga dengan mudah dipahami apa yang diajarkan.Moral perilaku yang baik adalah suatu perbuatan yang baik yang ada dalam diri seseorang.Seorang pendidik hendaknya mempunyai prilaku atau moral yang terpuji agar mampu menjadi contoh teladan bagi peserta didik sehingga dengan adanya moral ini seorang pendidik mampu mengontrol kelakuan maupun sikap saat mengajar sehingga tidak ada perbuatan atau sikap yang tidak diinginkan saat mengajar.

Kata kunci : Guru, professional, pendidikan
\end{abstract}

\begin{abstract}
Professional teachers are teachers who are able to educate their students into generations who are able to compete and have good morals. To achieve good educators, educators get it to be able to have a good character as well. Teacher professionalism is very beneficial for students because teachers need very heavy tasks in educating directing and motivating students to become students who are smart and moral. Characteristics is a trait that must be owned or mastered by an educator to produce a generation of dignified and moral. students where the right method can encourage the spirit of students to be more active in learning and also easily understand what is supported. Good moral motivation is about which is in a person. oral praise that is able to be an example for students so that with this morale the educator is able to control behavior and attitudes when teaching so that there are no unwanted actions or attitudes when teaching.
\end{abstract}

Keyword: Teacher, Professional, education 


\section{A. PENDAHULUAN}

Tidak ada yang akan menyangkal hakikat dari peran seorang guru. Guru apa pun itu. Sistem pendidikan nasional di Indonesia, yang merupakan salah satu garda terdepan pencapaian kesejahteraan bangsa, sedikit-banyak ditentukan oleh kualitas seorang guru. Maka tak heran jika sistem pendidikan nasional Indonesia menempatkan guru bukan semata sebagai suatu profesi. Guru di Indonesia diharapkan memiliki integritas dan profesionalitas dalam menjalankan tugas mulianya. Ada sejumlah kemampuan atau kompetensi penting yang diharapkan dimiliki oleh para guru. Kompetenesi pedagogik, misalnya. Kompetensi ini berkaitan dengan kemampuan mengelola pembelajaran peserta didik.

Seorang guru, setidaknya harus mampu menjadi pengelola kegiatan pembelajaran, mulai dari merencanakan, melaksanakan, hingga mengevaluasi proses pembelajaran yang dia laksanakan dengan baik. Kemudian ada pula kompetensi personal. Seorang guru tentu tidak cukup hanya memiliki kemampuan terkait dengan pelaksanaan proses pembelajaran. Seorang guru yang baik adalah seorang guru yang memiliki kepribadian yang arif, dewasa, mantap, berwibawa, sehingga dapat menjadi teladan bagi peserta didiknya. Selain itu, ada yang namanya kompetensi professional. Kompetensi ini terkait dengan kemampuan seorang guru terhadap penguasaan materi pembelajaran secara mendalam.

Seorang guru yang profesional adalah seorang guru yang memiliki pengetahuan yang luas, dan tidak sekadar text book terhadap bidang studi yang menjadi bahan ajarnya. Dengan memiliki kemampuan terhadap lapangan pengetahuannya, seorang guru tentu bisa memilih model, strategi, dan metode pengajaran yang tepat untuk murid-muridnya. Kompetensi yang juga tak kalah penting untuk dimiliki seorang guru adalah kompetensi sosial. Seorang guru pertama-tama haruslah menyadari peran pentingnya sebagai bagian dari masyarakat. Dia mengetahui apa dan bagaimana seharusnya mereka menjalankan kehidupannya di tengah-tengah masyarakat. Dengan demikian, sosok guru sebagai tenaga 


\section{Jurnal Asy-Syukriyyah}

pendidik tidak hanya muncul di dalam ruang kelas, tetapi juga ruang-ruang kehidupan bermasyarakat lainnya.

\section{B. PEMBAHASAN}

\section{Pengertian Guru}

Dalam Kamus Besar Bahasa Indonesia, sebagaimana dijelaskan Mujtahid dalam bukunya yang berjudul "Pengembangan Profesi Guru",definisi guru adalah orang yang

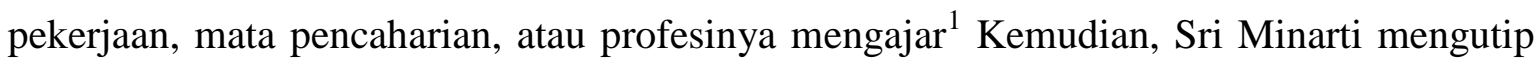
pendapat ahli bahasa Belanda, J.E.C. Gericke dan T. Roorda, yang menerangkan bahwa guru berasal dari bahasa Sansekerta yang artinya berat, besar, penting, baik sekali, terhormat, dan pengajar. Sementara dalam bahasa Inggris dijumpai beberapa kata yang berarti guru, misalnya teacher yang berarti guru atau pengajar, educator yang berarti pendidik atau ahli mendidik, dan tutor yang berarti guru pribadi, guru yang mengajar di rumah, atau guru yang memberi les. ${ }^{2}$

Dalam pengertian yang sederhana, guru adalah orang yang memberikan ilmu pengetahuan kepada anak didik. Kemudian guru dalam pandangan masyarakat adalah orang yang melaksanakan pendidikan di tempat-tempat tertentu, tidak harus di lembaga pendidikan formal, tetapi bisa juga di masjid, di surau atau mushola, di rumah dan sebagainya ${ }^{3}$.Sementara Supardi dalam bukunya yang berjudul "Kinerja Guru" menjelaskan pengertian guru menurut Undang-Undang Republik Indonesia Nomor 14 Tahun 2005 tentang Guru dan Dosen, bahwa guru adalah pendidik profesional dengan tugas utama mendidik, mengajar, membimbing, mengarahkan, melatih, menilai, dan mengevaluasi

\footnotetext{
${ }^{1}$ Mujtahid, Pengembangan Profesi Guru, (Malang: UIN Maliki Press, 2011), hlm. 33.

${ }^{2}$ Sri Minarti, Ilmu Pendidikan Islam: Fakta Teoritis-Filosofis dan Aplikatif-Normatif, (Jakarta: Amzah, 2013), hlm. 107-108.

${ }^{3}$ Syaiful Bahri Djamarah, Guru dan Anak Didik dalam Interaksi Edukatif: Suatu Pendekatan Teoretis Psikologis, (Jakarta: Rineka Cipta, 2010), hlm. 31.
} 


\section{Jurnal Asy-Syukriyyah}

peserta didik pada pendidikan usia dini, pendidikan dasar, dan pendidikan menengah jalur pendidikan formal. $^{4}$

Selanjutnya dalam literatur kependidikan Islam, banyak sekali katakata yang mengacu pada pengertian guru, seperti murabbi, mu'allim, dan muaddib. Ketiga kata tersebut memiliki fungsi penggunaan yang berbeda beda. ${ }^{5}$ Menurut para ahli bahasa, kata murabbi berasal dari kata rabba yurabbi yang berarti membimbing, mengurus, mengasuh, dan mendidik. Sementara kata mu'allim merupakan bentuk isim fa'il dari 'allama yu'allimu yang biasa diterjemahkan mengajar atau mengajarkan. ${ }^{6}$ Hal ini sebagaimana ditemukan dalam firman Allah sebagai berikut:

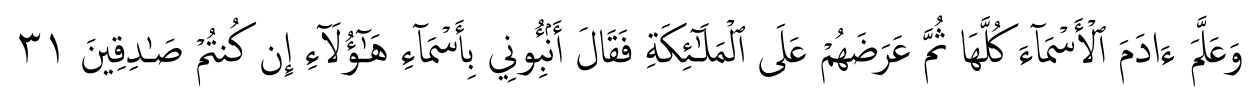

Dan Dia mengajarkan kepada Adam nama-nama (benda-benda) seluruhnya,kemudian mengemukakannya kepada Para Malaikat lalu berfirman:"Sebutkanlah kepada-Ku nama benda-benda itu jika kamu mamang benar orang-orang yang benar!"" (Q.S. al-Baqarah/2: 31)

Allah mengajarkan kepada Adam nama semua benda, termasuk mangkuk besar. Kemudian mengemukakan nama-nama benda tersebut kepada para malaikat ${ }^{8}$. Dengan demikian, 'allama disini diterjemahkan dengan mengajar. Selanjutnya istilah muaddib berasal dari akar kata addaba yuaddibu yang artinya mendidik. ${ }^{9}$ Di samping itu, seorang guru juga biasa disebut sebagai ustadż. Menurut Muhaimin, kata ustadz mengandung makna bahwa seorang guru dituntut untuk komitmen terhadap profesionalisme dalam mengemban tugasnya, dan dikatakan profesional apabila pada dirinya melekat sikap dedikatif yang tinggi terhadap tugasnya, sikap komitmen terhadap mutu proses dan hasil

${ }^{4}$ Supardi, Kinerja Guru, (Jakarta: PT RajaGrafindo Persada, 2014), hlm. 8

${ }^{5}$ Sri Minarti, Ilmu Pendidikan Islam..., hlm.108.

${ }^{6}$ Heri Gunawan, Pendidikan Islam: Kajian Teoritis dan Pemikiran Tokoh, (Bandung: PT Remaja Rosdakarya, 2014), hlm. 163.

${ }^{7}$ Departemen Agama RI, Al-Qur'an dan Terjemahannya, hlm. 6. Jilid 1, hlm. 48

${ }^{8}$ Syaikh Muhammad Ali Ash-Shabuni, Shafwatut Tafāsir, (Beirut: Dar al-Qur"an al-Karim, t.t.), hlm. 39.

${ }^{9}$ Mahmud Yunus, Kamus Arab Indonesia, (Jakarta: PT Mahmud Yunus Wa Dzuriyyah, 2010), 


\section{Jurnal Asy-Syukriyyah}

kerja, serta sikap continous improvement, yakni selalu berusaha memperbaiki dan memperbaharui model-model atau cara kerjanya sesuai dengan tuntutan zamannya yang dilandasi oleh kesadaran yang tinggi bahwa tugas mendidik adalah tugas menyiapkan generasi penerus yang hidup di masa depan. ${ }^{10}$ Kemudian selain yang telah dipaparkan di atas, dalam bahasa Arab guru juga sering disebut dengan mudarris yang merupakan isim fa'il dari darrasa, dan berasal dari kata darasa, yang berarti meninggalkan bekas, maksudnya guru mempunyai tugas dan kewajiban membuat bekas dalam jiwa peserta didik. Bekas itu merupakan hasil pembelajaran yang berwujud perubahan perilaku, sikap, dan penambahan atau pengembangan ilmu pengetahuan ${ }^{11}$.

Menurut Muhammad Muntahibun Nafis, guru adalah bapak ruhani (spiritual father) bagi peserta didik, yang memberikan ilmu, pembinaan akhlak mulia, dan meluruskan perilaku yang buruk. Oleh karena itu, guru memiliki kedudukan yang tinggi dalam Islam sebagaimana dinyatakan dalam beberapa teks, di antaranya disebutkan: "Tinta seorang ilmuwan (yang menjadi guru) lebih berharga ketimbang darah para syuhada". Muhammad Muntahibun Nafis juga mengutip pendapat Al-Syauki yang menempatkan guru setingkat dengan derajat seorang rasul. Dia bersyair: "Berdiri dan hormatilah guru. dan berilah penghargaan, seorang guru hampir saja merupakan seorang rasul". ${ }^{2}$

Kemudian, Abidin Ibnu Rusn mengutip pendapat Al-Ghazali yang menyatakan bahwa profesi keguruan merupakan profesi yang paling mulia dan paling agung dibanding dengan profesi yang lain. Al-Ghazali berkata:"Seorang yang berilmu dan kemudian bekerja dengan ilmunya itu, dialah yang dinamakan orang besar di bawah kolong langit ini. Ia bagai matahari yang mencahayai orang lain, sedangkan dia sendiri pun bercahaya. Ibarat minyak kasturi yang baunya dinikmati orang lain, ia sendiri pun harum ${ }^{13}$."

${ }^{10}$ Muhaimin, Wacana Pengembangan Pendidikan Islam, (Surabaya: PSAPM, 2014), hlm. 209-

210.

${ }^{11}$ Kadar M. Yusuf, Tafsir Tarbawi: Pesan-Pesan Al-Qur'an tentang Pendidikan, (Jakarta: Amzah, 2013), hlm. 63.

${ }^{12}$ Muhammad Muntahibun Nafis, Ilmu Pendidikan Islam, (Yogyakarta: Teras, 2011), hlm. 88.

13 Abidin Ibnu Rusn, Pemikiran Al-Ghazali tentang Pendidikan Islam, (Yogyakarta: Pustaka Pelajar, 2009), hlm. 63-64. 


\section{Jurnal Asy-Syukriyyah}

Jika direnungkan, tugas guru seperti tugas para utusan Allah. Rasulullah sebagai mu'allimul awwal fi al-Islam (guru pertama dalam Islam). bertugas membacakan, menyampaikan, dan mengajarkan ayat-ayat Allah (al-Qurean) kepada manusia, menyucikan diri dan jiwa dari dosa, menjelaskan mana yang halal dan mana yang haram, dan menceritakan tentang manusia di zaman silam kemudian dikaitkan pada zamannya serta memprediksikan kehidupan di zaman yang akan datang. ${ }^{14}$ Dengan demikian, tampaklah bahwa secara umum guru bertugas dan bertanggung jawab seperti rasul, yaitu mengantarkan murid dan menjadikannya manusia terdidik yang mampu menjalankan tugas-tugas ketuhanan dan tugas-tugas kemanusiaan.

\section{Kompetensi Guru}

Untuk menjadi guru yang profesional tidaklah mudah, karena harus memiliki berbagai kompetensi keguruan. Menurut Syaiful Sagala kompetensi adalah kemampuan melaksanakan sesuatu yang diperoleh melalui pendidikan dan latihan ${ }^{15}$. Di dalam UndangUndang Republik Indonesia Nomor 14 tahun 2005 Pasal 10 menyatakan bahwa kompetensi guru meliputi kompetensi pedagogik, kepribadian, sosial, dan profesional yang diperoleh melalui pendidikan profesi. ${ }^{16}$

a. Kompetensi Pedagogik

Kompetensi pedagogik merupakan kemampuan dalam pengelolaan peserta didik, yang meliputi:

1) Pemahaman wawasan guru akan landasan dan filsafat pendidikan.

2) Guru memahami potensi dan keberagaman peserta didik, sehingga dapat didesain strategi pelayanan belajar sesuai keunikan peserta didik.

3) Guru mampu mengembangkan kurikulum/silabus dalam bentuk dokumen maupun implementasi dalam bentuk pengamalan belajar.

${ }^{14}$ Rusn, Pemikiran Al-Ghazali..., hlm. 64

15 Syaiful Sagala, Kemampuan Profesional Guru dan Tenaga Kependidikan, (Bandung: Alfabeta, 2009), hlm. 29.

${ }^{16}$ Undang-Undang Guru dan Dosen (UU RI No. 14 Th. 2005), (Jakarta: Sinar Grafika, 2010), hlm. 9 


\section{Jurnal Asy-Syukriyyah}

4) Guru mampu menyusun rencana dan strategi pembelajaran berdasarkan standar kompetensi dan kompetensi dasar.

5) Mampu melaksanakan pembelajaran yang mendidik dengan suasana dialogis dan interaktif.

6) Mampu melakukan evaluasi hasil belajar dengan memenuhi prosedur dan standar yang dipersyaratkan.

7) Mampu mengembangkan bakat dan minat peserta didik melalui kegiatan intrakulikuler dan ekstrakulikuler untuk mengaktualisasikan berbagai potensi yang dimilikinya. ${ }^{17}$

b. Kompetensi Kepribadian

Kompetensi kepribadian terkait dengan penampilan sosok guru sebagai individu yang mempunyai kedisiplinan, berpenampilan baik, bertanggung jawab, memiliki komitmen, dan menjadi teladan. Menurut Usman yang dikutip oleh Syaiful Sagala, kompetensi kepribadian meliputi:

1) Kemampuan mengembangkan kepribadian.

2) Kemampuan berinteraksi dan berkomunikasi.

3) Kemampuan melaksanakan bimbingan dan penyuluhan ${ }^{18}$.

c. Kompetensi Sosial

Kompetensi sosial terkait dengan kemampuan guru sebagai makhluk sosial dalam berinteraksi dengan orang lain. Kompetensi social menurut Slamet PH sebagaimana dijelaskan oleh Syaifudin Sagala antara lain:

1) Memahami dan menghargai perbedaan (respek) serta memiliki kemampuan mengelola konflik.

2) Melaksanakan kerja sama secara harmonis dengan kawan sejawat, kepala sekolah, dan pihak-pihak terkait lainnya.

3) Membangun kerja tim (teamwork) yang kompak, cerdas, dinamis, dan lincah.

4) Melaksanakan komunikasi (oral, tertulis, tergambar) secara efektif dan menyenangkan dengan seluruh warga sekolah, orang tua peserta didik, dengan kesadaran sepenuhnya

${ }^{17}$ Syaiful Sagala, Kemampuan Profesional Guru..., hlm. 32.

${ }^{18}$ Syaiful Sagala, Kemampuan Profesional Guru..., hlm. 34 


\section{Jurnal Asy-Syukriyyah}

bahwa masing-masing memiliki peran dan tanggung jawab terhadap kemajuan pembelajaran.

5) Memiliki kemampuan memahami dan menginternalisasikanperubahan lingkungan yang berpengaruh dengan tugasnya.

6) Memiliki kemampuan mendudukkan dirinya dalam sistem nilai yang berlaku di masyarakat.

7) Melakukan prinsip-prinsip tata kelola yang baik (partisipasi, penegakan hukum, dan profesionalisme). ${ }^{19}$

d. Kompetensi Profesional Kompetensi profesional berkaitan dengan bidang studi, menurut Syaifudin Sagala terdiri dari:

1) Memahami mata pelajaran yang telah dipersiapkan untuk mengajar,

2) Memahami standar kompetensi dan standar isi mata pelajaran serta bahan ajar yang ada dalam kurikulum.

3) Memahami struktur, konsep, dan metode keilmuan yang menaungi materi ajar.

4) Memahami hubungan konsep antar mata pelajaran terkait.

5) Menerapkan konsep-konsep keilmuan dalam kehidupan sehari-hari. ${ }^{20}$

Menurut Bukhari Umar, untuk mewujudkan guru yang profesional, dapat mengacu pada tuntunan Nabi saw, karena beliau satu-satunya guru yang paling berhasil dalam rentang waktu yang singkat, sehingga diharapkan dapat mendekatkan pada realitas (guru) yang ideal (Nabi saw). Keberhasilan Nabi saw sebagai guru didahului oleh bekal kepribadian (personality) yang berkualitas unggul, kepeduliannya terhadap masalah-masalah sosial religus serta semangat dan ketajaman dalam iqra' bi ismi rabbik (membaca, menganalisis, meneliti, dan mengeksperimentasi terhadap berbagai fenomena kehidupan dengan menyebut nama Tuhan). Kemudian, beliau mampu bertahan dan mengembangkan kualitas iman, amal shaleh, berjuang, dan bekerja sama menegakkan kebenaran. ${ }^{21}$ Berdasarkan paparan tersebut, Bukhari Umar

\footnotetext{
${ }^{19}$ Syaiful Sagala, Kemampuan Profesional Guru..., hlm. 38.

${ }^{20}$ Syaiful Sagala, Kemampuan Profesional Guru..., hlm. 39-40.

${ }^{21}$ Bukhari Umar, Ilmu Pendidikan Islam, hlm. 93.
} 
mengformulasikan asumsi yang melandasi keberhasilan guru dalam menjalankan tugasnya adalah guru yang mempunyai beberapa kompetensi sebagai berikut:

a. Kompetensi Personal-Religius

Kemampuan yang menyangkut kepribadian agamis, artinya pada dirinya melekat nilai-nilai lebih yang hendak ditransinternalisasikan (pemindahan penghayatan nilai-nilai) kepada peserta didik. Misalnya nilai kejujuran, amanah, keadilan, kecerdasan, tanggung jawab, musyawarah, kedisiplinan, dan sebagainya. Nilai tersebut perlu dimiliki guru sehingga akan terjadi transinternalisasi antara guru dan peserta didik, baik langsung maupun tidak langsung.

b. Kompetensi Sosial-Religus

Kemampuan yang menyangkut kepedulian terhadap masalahmasalah sosial yang selaras dengan ajaran dakwah Islam. Sikap gotong royong, tolong-menolong, egalitarian (persamaan derajat antara manusia), sikap toleransi, dan sebagainya juga perlu dimiliki oleh guru dalam rangka transinternalisasi sosial.

c. Kompetensi Profesional-Religius

Kemampuan ini menyangkut kemampuan untuk menjalankan tugas keguruan secara profesional, dalam arti mampu membuat keputusan atas beragamnya kasus dan dapat mempertanggungjawabkannya berdasarkan teori dan wawasan keahliannya dalam perspektif Islam. $^{22}$ Kompetensi guru yang tidak kalah pentingnya adalah memberikan uswah hasanah kepada peserta didik dan meningkatkan kualitas serta profesionalitasnya yang mengacu pada masa depan peserta didik sehingga guru benar-benar berkemampuan tinggi dalam menghasilkan generasi muda yang mampu mencapai tujuan pendidikan.

\section{Kode Etik Profesi Guru}

Istilah kode etik terdiri dari dua kata, yakni kode dan etik. Menurut Syaiful Bahri Djamarah etik berasal dari bahasa Yunani yaitu ethos yang berarti watak, adab, atau cara

\footnotetext{
${ }^{22}$ Bukhari Umar, Ilmu Pendidikan Islam, hlm. 93-94.
} 
hidup. Etik biasanya dipakai untuk pengkajian sistem nilai-nilai yang disebut "kode", sehingga disebutlah kode etik. Etika artinya tata susila atau hal-hal yang berhubungan dengan kesusilaan dalam mengerjakan suatu pekerjaan. Jadi "kode etik guru" diartikan sebagai aturanaturan tata susila keguruan. ${ }^{23}$

Kode etik guru Indonesia dapat dirumuskan sebagai himpunan nila inilai dan norma-norma profesi guru yang tersusun dengan baik dan sistematik dalam suatu sistem yang utuh dan bulat. Fungsi kode etik guru Indonesia adalah sebagai landasan moral dan pedoman tingkah laku setiap guru dalam menunaikan tugas pengabdiannya sebagai guru, baik di dalam maupun di luar sekolah serta dalam kehidupan sehari-hari di masyarakat. ${ }^{24}$ Kode etik guru ditetapkan oleh anggota profesi guru yang tergabung dalam wadah PGRI. Kode etik ini dijadikan pedoman bertindak bagi seluruh anggota organisasi atau profesi tersebut. ${ }^{25}$ Berdasarkan hasil rumusan Kongres PGRI XIII dari seluruh penjuru tanah air di Jakarta tahun 1973, dan kemudian disempurnakan dalam Kongres PGRI XVI tahun 1989 di Jakarta juga, kode etik guru Indonesia antara lain:

a. Guru berbakti membimbing peserta didik untuk membentuk manusia Indonesia seutuhnya yang berjiwa Pancasila.

b. Guru memiliki dan melaksanakan kejujuran profesional.

c. Guru berusaha memperoleh informasi tentang peserta didik sebagai bahan melakukan bimbingan dan pembinaan.

d. Guru menciptakan suasana sekolah sebaik-baiknya yang menunjang berhasilnya proses belajar-mengajar

e. Guru memelihara hubungan baik dengan orang tua murid dan masyarakat sekitarnya untuk membina peran serta dan rasa tanggung jawab bersama terhadap pendidikan.

f. Guru secara pribadi dan bersama-sama mengembangkan dan meningkatkan mutu dan martabat profesinya.

g. Guru memelihara hubungan seprofesi, semangat kekeluargaan, dan kesetiakawanan sosial.

${ }^{23}$ Djamarah, Guru dan Anak Didik..., hlm. 49.

${ }^{24}$ Soetjipto dan Raflis Kosasi, Profesi Keguruan, (Jakarta: Rineka Cipta, 2009), hlm. 33-34

${ }^{25}$ Djam"ean Satori, dkk, Profesi Keguruan, (Jakarta: Universitas Terbuka, 2007), hlm. 1.24 


\section{Jurnal Asy-Syukriyyah}

h. Guru secara bersama-sama memelihara dan meningkatkan mutu organisasi PGRI sebagai sarana perjuangan dan pengabdian.i. Guru melaksanakan segala kebijakan pemerintah dalam bidang pendidikan. ${ }^{26}$

Dalam merumuskan kode etik, Bukhari Umar mengutip pendapat Al-Ghazali yang lebih menekankan betapa berat kode etik yang diperankan seorang guru daripada peserta didiknya. Kode etik tersebut antara lain:

1. Menerima segala problem peserta didik dengan hati dan sikap yang terbuka, tabah, dan meninggalkan sifat marah.

2. Bersikap penyantun dan penyayang.

3. Menjaga kewibawaan dan kehormatannya dalam bertindak.

4. Menghindari dan menghilangkan sikap angkuh terhadap sesama.

5. Bersifat rendah hati ketika menyatu dengan sekelompok masyarakat. ${ }^{27}$

6. Menghilangkan aktivitas yang tidak berguna dan sia-sia.

7. Bersifat lemah lembut dalam menghadapi peserta didik yang tingkat IQ nya rendah, serta membinanya sampai pada taraf maksimal.

8. Meninggalkan sifat yang menakutkan bagi peserta didik, terutama pada peserta didik yang belum mengerti.

9. Berusaha memperhatikan pertanyaan-pertanyaan peserta didik, walaupun pertanyaannya terkesan tidak bermutu atau tidak sesuai dengan masalah yang diajarkan.

10. Menjadikan kebenaran sebagai acuan dalam proses pendidikan, walaupun kebenarannya itu datangnya dari peserta didik.

11. Mencegah dan mengontrol peserta didik mempelajari ilmu yang membahayakan.

12. Menanamkan ikhlas pada peserta didik, serta terus-menerus mencari informasi guna disampaikan pada peserta didik yang pada akhirnya mencapai tingkat taqarrub kepada Allah. Mencegah peserta didik mempelajari ilmu fardhu kifayah (kewajiban kolektif, seperti ilmu kedokteran, psikologi, ekonomi, dan sebagainya) sebelum mempelajari ilmu fardhu 'ain (kewajiban individual, seperti akidah, syarieeah, dan akhlak).

13. Mengaktualisasikan informasi yang diajarkan kepada peserta didik. ${ }^{28}$

\footnotetext{
${ }^{26}$ Soetjipto dan Raflis Kosasi, Profesi Keguruan, hlm. 34-35

${ }^{27}$ Bukhari Umar, Ilmu Pendidikan Islam, hlm. 99.
} 


\section{Tanggung Jawab Guru}

Menurut Oemar Hamalik, guru memiliki beberapa tanggung jawab antara lain:

a. Tanggung Jawab Moral

Setiap guru profesional berkewajiban menghayati dan mengamalkan Pancasila dan bertanggung jawab mewariskan moral

Pancasila serta nilai-nilai Undang-Undang Dasar 1945 kepada generasi muda. Tanggung jawab ini merupakan tanggung jawab moral bagi setiap guru di Indonesia. Dalam kemampuan ini setiap guru harus memiliki kompetensi dalam bentuk kemampuan menghayati dan mengamalkan Pancasila. ${ }^{29}$

b. Tanggung Jawab Dalam Bidang Pendidikan di Sekolah

Guru bertanggung jawab melaksanakan kegiatan pendidikan di sekolah dalam arti memberikan bimbingan dan pengajaran kepada para siswa. Tanggung jawab ini direalisasikan dalam bentuk melaksanakan pembinaan kurikulum, menuntun para siswa belajar, membina pribadi,watak, dan jasmaniah siswa, menganalisis kesulitan belajar, serta menilai kemajuan belajar para siswa. ${ }^{30}$

c. Tanggung Jawab Dalam Bidang Kemasyarakatan

Guru profesional tidak dapat melepaskan dirinya dari bidang kehidupan masyarakat. Di satu pihak, guru adalah warga dari masyarakat dan di pihak lain guru bertanggung jawab turut serta memajukan kehidupan masyarakat. Guru turut bertanggung jawab memajukan persatuan dan kesatuan bangsa, serta menyukseskan pembangunan nasional. Sehingga, guru harus menguasai dan memahami semua hal yang bertalian dengan kehidupan nasional misalnya tentang suku bangsa, adat istiadat, kebiasaan, norma-norma, kebutuhan, kondisi lingkungan, dan sebagainya $^{31}$.

\footnotetext{
${ }^{28}$ Bukhari Umar, Ilmu Pendidikan Islam, hlm. 99-100

${ }^{29}$ Oemar Hamalik, Pendidikan Guru: Berdasarkan Pendekatan Kompetensi, (Jakarta: PT Bumi Aksara, 2009), hlm. 39.

${ }^{30}$ Oemar Hamalik, Pendidikan Guru..., hlm. 40.

${ }^{31}$ Oemar Hamalik, Pendidikan Guru..., hlm. 41
} 


\section{Jurnal Asy-Syukriyyah}

d. Tanggung Jawab Dalam Bidang Keilmuan Guru

Sebagai ilmuwan bertanggung jawab turut memajukan ilmu, terutama ilmu yang telah menjadi spesialisasinya. Tanggung jawab ini dilaksanakan dalam bentuk mengadakan penelitian dan pengembangan. Guru harus memiliki kompetensi tentang cara mengadakan penelitian, seperti cara membuat desain penelitian, cara merumuskan masalah, cara menentukan alat pengumpulan data, cara mengadakan sampling, dan cara mengolah data dengan teknik statistik yang sesuai. Dan selanjutnya, guruharus mampu menyusun laporan hasil penelitian agar dapat disebarluaskan. ${ }^{32}$

\section{Tugas Guru}

Tugas Guru Menurut Undang-Undang Guru dan Dosen Menurut Mujtahid, tugas adalah aktivitas dan kewajiban yang harus diformasikan oleh seseorang dalam memainkan peranan tertentu. ${ }^{33}$ Dalam Undang-Undang Nomor 14 Tahun 2005 tentang Guru dan Dosen Bab I Pasal 1, dijelaskan bahwa guru adalah pendidik profesional dengan tugas utama mendidik, mengajar, membimbing, mengarahkan, melatih, menilai, dan mengevaluasi peserta didik pada pendidikan usia dini jalur pendidikan formal, pendidikan dasar, dan pendidikan menengah. ${ }^{34}$ Untuk menjabarkan rumusan tersebut di atas, berikut ini merupakan penjelasan guru sebagai pendidik, pembimbing, dan pelatih.

a. Guru Sebagai Pendidik

Menurut Undang-Undang No. 20 Tahun 2005 tentang Guru dan Dosen Bab II Pasal 39 ayat 2, pendidik merupakan tenaga professional yang bertugas merencanakan dan melaksanakan proses pembelajaran, melakukan pembimbingan dan pelatihan, serta melakukan pelatihan dan pengabdian kepada masyarakat. ${ }^{35}$ Mujtahid dalam salah satu tulisannya, mengutip pendapat Muchtar Buchori yang memberikan

\footnotetext{
${ }^{32}$ Oemar Hamalik, Pendidikan Guru..., hlm. 42.

${ }^{33}$ Mujtahid, Pengembangan Profesi Guru, hlm. 44.

${ }^{34}$ Undang-Undang Guru dan Dosen..., hlm. 3.

${ }^{35}$ Mujtahid, Pengembangan Profesi Guru, hlm. 44.
} 


\section{Jurnal Asy-Syukriyyah}

penjelasan bahwa yang dimaksud dengan mendidik adalah proses kegiatan untuk mengembangkan pandangan hidup, sikap hidup, dan keterampilan hidup pada diri seseorang. 36

b. Guru Sebagai Pembimbing

Guru berusaha membimbing peserta didik agar dapat menemukan berbagai potensi yang dimilikinya, dan dapat tumbuh serta berkembang menjadi individu yang mandiri dan produktif. Tugas guru sebagai pembimbing terletak pada kekuatan intensitas hubungan interpersonal antara guru dengan peserta didik yang dibimbingnya. Guru juga dituntut agar mampu mengidentifikasi peserta didik yang diduga mengalami kesulitan dalam belajar, melakukan diagnosa, dan membantu memecahkannya.

c. Guru Sebagai Pelatih

Guru juga harus bertindak sebagai pelatih, karena pendidikan dan pengajaran memerlukan bantuan latihan keterampilan baik intelektual, sikap, maupun motorik. Agar dapat berpikir kritis, berperilaku sopan, dan menguasai keterampilan, peserta didik harus mengalami banyak latihan yang teratur dan konsisten. Kegiatan mendidik atau mengajar juga tentu membutuhkan latihan untuk memperdalam pemahaman dan penerapan teori yang disampaikan. ${ }^{37}$ Selain yang disebutkan di atas, Undang-Undang Republik Indonesia Nomor 14 Tahun 2005 tentang Guru dan Dosen juga mencantumkan tugas guru yang terdapat dalam Bab IV Pasal 20, antara lain:

a) Merencanakan pembelajaran, melaksanakan proses pembelajaran yang bermutu, serta menilai dan mengevaluasi hasil pembelajaran.

b) Meningkatkan dan mengembangkan kualifikasi akademik dan kompetensi secara berkelanjutan sejalan dengan perkembangan ilmu pengetahuan, teknologi, dan seni.

${ }^{36}$ Mujtahid, Pengembangan Profesi Guru, hlm. 45.
${ }^{37}$ Mujtahid, Pengembangan Profesi Guru, hlm. 50 


\section{Jurnal Asy-Syukriyyah}

c) Bertindak objektif dan tidak diskriminatif atas dasar pertimbangan jenis kelamin, agama, suku, ras, dan kondisi fisik tertentu atau latar belakang keluarga, dan status sosial ekonomi peserta didik dalam pembelajaran.

d) Menjunjung tinggi peraturan perundang-undangan, hukum, dan kode etik guru, serta nilai-nilai agama dan etika.

e) Memelihara dan memupuk persatuan dan kesatuan bangsa. ${ }^{38}$

Tugas Guru Menurut Pendidikan Islam Seorang guru dalam pandangan Islam memiliki kedudukan yang sangat mulia. Islam sangat menghargai orang-orang yang berilmu pengetahuan (guru), sehingga hanya mereka sajalah yang pantas mencapai taraf ketinggian dan keutuhan hidup. ${ }^{39}$ Allah berfirman:

Hai orang-orang beriman apabila kamu dikatakan kepadamu: "Berlapanglapanglah dalam majlis", Maka lapangkanlah niscaya Allah akan member kelapangan untukmu. dan apabila dikatakan: "Berdirilah kamu", Maka berdirilah, niscaya Allah akan meninggikan orang-orang yang beriman diantaramu dan orang-orang yang diberi ilmu pengetahuan beberapa derajat dan Allah Maha mengetahui apa yang kamu kerjakan. ${ }^{40}$ (Q.S. al-Mujaadalah/58:11)

Syaikh Muhammad Syakir menjelaskan bahwa Allah akan mengangkat derajat orang-orang dan orang-orang yang diberi ilmu pengetahuan. dan Allah Maha teliti terhadap orang-orang yang berhak mendapatkan ketinggian derajat. ${ }^{41}$ Keutamaan seorang guru disebabkan oleh tugas mulia yang diembannya, karena tugas mulia dan berat yang dipikul hampir sama dengan tugas seorang rasul. Muhammad Muntahibun Nafis mengatakan bahwa tugas guru adalah sebagai warasat al-anbiya', yang pada hakikatnya mengemban misi rahmat lil 'alamin, yaitu misi yang mengajak manusia untuk tunduk dan patuh pada hukum-hukum Allah, guna memperoleh keselamatan dan kebahagiaan di dunia dan di akhirat. Kemudian misi itu dikembangkan pada suatu upaya pembentukan karakter

${ }^{38}$ Undang-Undang Guru dan Dosen..., hlm. 14-15.

${ }^{39}$ Zakiah Darajat, dkk, Ilmu Pendidikan Islam, (Jakarta: Bumi Aksara, 2014), hlm. 40.

${ }^{40}$ Departemen Agama RI, Al-Qur'an dan Terjemahannya, hlm. 793.

${ }^{41}$ Abi Fada ${ }^{e e}$ Al-Hafidz Ibnu Katsir Al-Damsyiqi, Tafsir Al-Qur'an Al-Adzim, (Beirut: alMaktabah al-,,Ilmiyah,t.t.), Jil. 4, hlm. 305. 
kepribadian yang berjiwa tauhid, kreatif, beramal sholeh, dan bermoral tinggi. Dan kunci untuk melaksanakan tugas tersebut, guru dapat berpegangan pada amar ma'ruf nahi munkar, menjadikan prinsip tauhid sebagai pusat kegiatan penyebaran misi iman, Islam, dan ihsan. ${ }^{42}$

Dalam pandangan Al-Ghazali yang dikutip oleh Muhammad Muntahibun Nafis, seorang guru mempunyai tugas yang utama yaitu menyempurnakan, membersihkan, menyucikan, serta membawakan hati manusia untuk mendekatkan diri (taqarrub) kepada Allah swt. Hal ini karenapada dasarnya tujuan utama pendidikan Islam adalah untuk mendekatkan diri kepada Allah swt, kemudian realisasinya pada kesalehan sosial dalam masyarakat sekelilingnya. ${ }^{43}$ Dari sini dapat dinyatakan bahwa kesuksesan seorang guru akan dapat dilihat dari keberhasilan aktualisasi perpaduan antara iman, ilmu, dan amal saleh dari peserta didiknya setelah mengalami sebuah proses pendidikan.Berkaitan dengan tugas guru, Abidin Ibnu Rusn juga mengutip pendapat al-Ghazali, beliau menyebutkan beberapa hal sebagai berikut:

1. Guru adalah Orang Tua Kedua di Depan Murid

Seorang guru akan berhasil melaksanakan tugasnya apabila mempunyai rasa tanggung jawab dan kasih sayang terhadap muridnya sebagaimana orang tua terhadap anaknya sendiri. Tugas guru tidak hanya menyampaikan pelajaran, tetapi juga berperan seperti orang tua. ${ }^{44}$

2. Guru Sebagai Pewaris Ilmu Nabi

Seorang guru yang mengajarkan ilmu pengetahuan, baik ilmu dunia maupun ilmu akhirat, harus mengarah kepada tujuan hidup muridnya yaitu mencapai hidup bahagia dunia akhirat. Guru harus membimbing muridnya agar ia belajar bukan karena ijazah semata, hanya bertujuan menumpuk harta, menggapai kemewahan

${ }^{42}$ Abi Fadae Al-Hafidz Ibnu Katsir Al-Damsyiqi, Tafsir Al-Qur'an Al-Adzim, (Beirut: alMaktabah al-,,Ilmiyah,t.t.), Jil. 4, hlm. 305.

${ }^{43}$ Nafis, Ilmu Pendidikan Islam, hlm. 90.

${ }^{44}$ Rusn, Pemikiran Al-Ghazali..., hlm. 67. 
dunia, pangkat dan kedudukan, maupun kehormatan dan popularitas, melainkan untuk mengharap ridha Allah. ${ }^{45}$

3. Guru Sebagai Penunjuk Jalan Dan Pembimbing Keagamaan Murid Berdasarkan keikhlasan dan kasih sayangnya, guru selanjutnya bertugas sebagai penunjuk jalan bagi murid dalam mempelajari dan mengkaji pengetahuan dalam berbagai disiplin ilmu. Guru juga harus memberi nasehat kepada murid untuk meluruskan niat, bahwa tujuan belajar tidak hanya untuk meraih prestasi duniawi, tetapi yang lebih penting adalah untuk mengembangkan ilmu itu sendiri, menyebarluaskannya, dan mendekatkan diri kepada Allah. ${ }^{46}$

4. Guru Sebagai Sentral Figur Bagi Murid

Al-Ghazali menasehatkan kepada setiap guru agar senantiasa menjadi teladan dan pusat perhatian bagi muridnya. Ia harus mempunyai karisma yang tinggi. Di samping itu, kewibawaan juga sangat menunjang dalam perannya sebagai pembimbing dan penunjuk jalan dalam masa studi muridnya. ${ }^{47}$

5. Guru Sebagai Motivator Bagi Murid

Guru harus memberikan peluang kepada murid untuk mengkaji berbagai ilmu pengetahuan, yakni memberikan dorongan kepada muridnya agar senang belajar. ${ }^{48}$

6. Guru Sebagai Seorang Yang Memahami Tingkat Perkembangan Intelektual

murid Menurut Al-Ghazali, usia manusia sangat berhubungan erat dengan perkembangan intelektualnya. Anak berusia 0-6 tahun berbeda tingkat pemahamannya dengan anak berusia 6-9 tahun, anak berusia 6-9 tahun berbeda dengan anak berusia 9-13 tahun, dan seterusnya. Atas dasar inilah Al-Ghazali mengingatkan agar guru dapat menyampaikan ilmu pengetahuan dalam proses belajar mengajar sesuai dengan tingkat pemahaman murid. ${ }^{49}$ Menurut Whiterington

\footnotetext{
${ }^{45}$ Rusn, Pemikiran Al-Ghazali..., hlm. 68.

${ }^{46}$ Rusn, Pemikiran Al-Ghazali..., hlm. 69-70.

${ }^{47}$ Rusn, Pemikiran Al-Ghazali..., hlm. 70-71.

${ }^{48}$ Rusn, Pemikiran Al-Ghazali..., hlm. 71-72.

${ }^{49}$ Rusn, Pemikiran Al-Ghazali..., hlm. 73-74
} 
sebagaimana dijelaskan oleh Abidin Ibnu Rusn dalam bukunya yang berjudul "Pemikiran Al-Ghazali tentang Pendidikan", pada setiap periode pertumbuhan, manusia mempunyai tanda aktivitas fisik dan psikis yang berbeda. Karena itu, guru sebagai penggali potensi intelektual murid harus dapat menjadi pembimbing selama pertumbuhan dan perkembangannya ${ }^{50}$.

\section{KESIMPULAN}

Guru sebagai pendidik adalah pribadi yang paling banyak bergaul dan berinteraksi dengan para murid dibandingkan dengan personel lainnya di sekolah. Guru bertugas merencanakan dan melaksanakan proses pembelajaran, menilai hasil pembelajaran, melakukan bimbingan dan pelatihan, melakukan penelitian dan pengkajian, dan membuka komunikasi dengan masyarakat, menggerakkan dan mendorong peserta didik agar semangat dalam belajar, sehingga semangat belajar peserta didik benar-benar dapat menguasai bidang ilmu yang dipelajari.

Ada terdapat tiga ciri guru profesional yang harus dimiliki oleh para tenaga pendidik: Pertama, guru guru harus memenuhi kompetensi dan keahlian inti sebagai pendidik. perubahan zaman mendorong guru untuk dapat menghadirkan pembelajaran abad 21 yaitu menyiapkan peserta didik untuk memiliki keterampilan berpikir kritis, kreatif, inovatif, komunikatif, dan mampu berkolaborasi. "hal tersebut tentu tidak akan dapat diwujudkan jika para guru berhenti belajar dan mengembangkan diri,". Kedua, seorang guru hendaknya mampu membangun kesejawatan dan mengembangkan diri serta meningkatkan kecakapan untuk mengikuti laju perubahan zaman. Jiwa korsa guru harus senantiasa dipupuk agar dapat membantu dan mengontrol satu sama lain. Ketiga, seorang guru hendaknya mampu merawat jiwa sosial. para guru Indonesia adalah para pejuang pendidikan yang sesungguhnya yang menjalankan peran tugas dan tanggung. Dengan segala tantangan dan hambatan, Mendikbud mengajak para guru untuk selalu berada di garda terdepan dalam pencerdasan kehidupan bangsa.

${ }^{50}$ Rusn, Pemikiran Al-Ghazali..., hlm. 74. 


\section{Jurnal Asy-Syukriyyah}

\section{DAFTAR PUSTAKA}

Abi Fadae Al-Hafidz Ibnu Katsir Al-Damsyiqi, Tafsir Al-Qur'an Al-Adzim, (Beirut: alMaktabah al-,,Ilmiyah,t.t.), Jil. 4

Abidin Ibnu Rusn, Pemikiran Al-Ghazali tentang Pendidikan Islam, (Yogyakarta: Pustaka Pelajar, 2009),

atori, dkk, Profesi Keguruan, (Jakarta: Universitas Terbuka, 2007),

Djam eean S Kadar M. Yusuf, Tafsir Tarbawi: Pesan-Pesan Al-Qur'an tentang Pendidikan, (Jakarta:, 2013),

Departemen Agama RI, Al-Qur'an dan Terjemahannya,

Heri Gunawan, Pendidikan Islam: Kajian Teoritis dan Pemikiran Tokoh, (Bandung: PT Remaja Rosdakarya, 2014),

Mujtahid, Pengembangan Profesi Guru, (Malang: UIN Maliki Press, 2011),

Sri Minarti, Ilmu Pendidikan Islam: Fakta Teoritis-Filosofis dan Aplikatif-Normatif, (Jakarta: Amzah, 2013),

Syaiful Bahri Djamarah, Guru dan Anak Didik dalam Interaksi Edukatif: Suatu Pendekatan Teoretis Psikologis, (Jakarta: Rineka Cipta, 2010),

Supardi, Kinerja Guru, (Jakarta: PT RajaGrafindo Persada, 2014),

Syaikh Muhammad Ali Ash-Shabuni, Shafwatut Tafāsir, (Beirut: Dar al-Qur"an al-Karim, t.t.), Jilid 1,

Mahmud Yunus, Kamus Arab Indonesia, (Jakarta: PT Mahmud Yunus Wa Dzuriyyah, 2010),

Kadar M. Yusuf, Tafsir Tarbawi: Pesan-Pesan Al-Qur'an tentang Pendidikan, (Jakarta:A

Muhaimin, Wacana Pengembangan Pendidikan Islam, (Surabaya: PSAPM, 2014),

Muhammad Muntahibun Nafis, Ilmu Pendidikan Islam, (Yogyakarta: Teras, 2011), 


\section{Jurnal Asy-Syukriyyah}

Oemar Hamalik, Pendidikan Guru: Berdasarkan Pendekatan Kompetensi, (Jakarta: PT Bumi Aksara, 2009),

Syaiful Sagala, Kemampuan Profesional Guru dan Tenaga Kependidikan, (Bandung: Alfabeta, 2009),

Soetjipto dan Raflis Kosasi, Profesi Keguruan, (Jakarta: Rineka Cipta, 2009),

Undang-Undang Guru dan Dosen (UU RI No. 14 Th. 2005), (Jakarta: Sinar Grafika, 2010),

Zakiah Darajat, dkk, Ilmu Pendiidkan Islam, (Jakarta: Bumi Aksara, 2014), 